\title{
EXAMINATION OF THE MOST COMMON ALLERGENS OF CANINE ATOPIC DERMATITIS - A RETROSPECTIVE STUDY
}

\author{
Nemanja Šubarevićl ${ }^{1 \star}$, Oliver Stevanović ${ }^{2}$ \\ Natalija Miličić Matić ${ }^{1}$, Nikola Popović ${ }^{1}$ \\ ${ }^{1}$ Faculty of Veterinary Medicine, Department of equine, small animal, \\ poultry and wild animal diseases University of Belgrade, Belgrade Serbia \\ ${ }^{2}$ PI Veterinary Institute of the Republic of Srpska “Dr. Vaso Butozan”, Banja Luka, \\ Republic of Srpska, Bosnia and Herzegovina
}

\section{Abstract}

Canine atopic dermatitis (CAD) is one of the most common skin diseases of dogs. It is estimated that $10-15 \%$ of the dogs are showing clinical symptoms of this disease. Canine atopic dermatitis is defined as genetically predisposed inflammatory and pruritic allergic skin disease with characteristic clinical symptoms. It is related to the production of IgE antibodies, mostly directed against external allergens. Allergens that can cause canine atopic dermatitis are quite numerous and depend on the geographical characteristics of research location. The aim of the study is to determine the most common allergens that can cause canine atopic dermatitis. The research was conducted according to medical records of 100 dogs during a period from the beginning of 2008 to the end of 2012 from the Department for skin diseases of small animals of the Clinic of equine, small animal, poultry and wild animal diseases at the Faculty of Veterinary Medicine, University of Belgrade. According to the clinical documentation, all of the tested dogs had clinically manifested symptoms of CAD. In order to confirm the diagnosis and detect the causative allergens, intradermal testing has been done. This testing has been performed with a standard set of 24 allergens specific to the geographical area of the research, produced in the Institute of Virology, Vaccines and Sera "Torlak". According to the results, the highest percentage of positive responses was established for the following allergens: house dust mites (Dermatophagoides sp.) $67 \%$, ragweed (Ambrosia artemisiifolia) $61 \%$, household dust $60 \%$, cocks foot (Dactylis sp.) $59 \%$, mix of weed pollen $57 \%$.

Key words: canine atopic dermatitis, $\mathrm{CAD}$, allergens, intradermal test

${ }^{1 *}$ E-mail: subic90@gmail.com 


\title{
ISPITIVANJE NAJČEŠĆIH ALERGENA ATOPIČNOG DERMATITISA PASA - RETROSPEKTIVA STUDIJA
}

\author{
Nemanja Šubarević1, Oliver Stevanović ${ }^{2}$, Natalija \\ Miličić Matić1, Nikola Popović ${ }^{1}$ \\ ${ }^{1}$ Departman za bolesti kopitara, mesojeda, živine i divljači, Fakultet \\ veterinarske medicine, Univerzitet u Beogradu, Beograd, Srbija \\ ${ }^{2}$ PI veterinarski institute Republke Srpske “Dr Vaso Butozan”, Banja Luka, \\ Republika Srpska, Bosna i Hercegovina
}

\section{Kratak sadržaj}

Atopični dermatitis pasa (ADP) je jedno od najčešćih oboljenja pasa. Procenjuje se da 10 do $15 \%$ pasa ispoljava kliničke simptome bolesti. Atopični dermatitis pasa se definiše kao genetički predisponirajuće oboljenje koje prati inflamatorni tok i alergijski svrab. Oboljenje nastaje zbog produkcije IgE antitela usmerenih na alergene iz spoljne sredine. Postoje mnogobrojni alergeni koji uzorkuju atopični dermatitis kod pasa zavisno od geografskih karakteristika lokacija koje se istražuju. Cilj studije je bio da se utvrdi koji su najčešći alergeni koji uzorkuju atopični dermatitis. Istraživanje je urađeno prema medicinskim protkolima za 100 pasa u period od početka 2008 do kraja 2012 godine iz ambulante za oboljenja kože Departmana za bolesti kopitara mesojeda, živine i divljači, na Faklutetu veterinarske medicine, Univerziteta u Beogradu. Prema kliničkoj dokumentaciji, svi testirani psi su imali kliničke manifestacije koje upoućuju na ADP. Kako bi potvrdili dijagnozu i detektovali uzročne alergene, potrebno je da se uradi intradermalni test. Navedeni test je urađen sa standardnim setom od 24 poznata alergena koji su specifični za geografsku oblast istraživanja, a proizvedeni su u Institutu za virusologiju, vakcine i serume "Torlak". Na osnovu dobijenih rezultata ustvrđeno je da je najčešći procenat pozitivnih odgovora dobijen kod sledećih alergena: grinja iz kućne prašine (Dermatophagoides sp.) 67\%, ambrozije (Ambrosia artemisiifolia) 61\%, kućne prašine $60 \%$, mačije trave (Dactylis sp.) 59\%, mešavine polena 57\%.

Ključne reči: atopični dermatitis pasa, $\mathrm{ADP}$, alergeni, intradermalni test 


\section{INTRODUCTION}

Canine atopic dermatitis (CAD) is one of the most common skin diseases of dogs. It is estimated that $10-15 \%$ of dogs are showing clinical symptoms of this disease (Williams, 2001).

CAD is defined as genetically predisposed inflammatory and pruritic allergic skin disease with characteristic clinical symptoms related to the production of IgE antibodies, mostly directed against external allergens (Halliwell, 2006). The pathogenesis of CAD is not yet entirely elucidated, but it is considered that a defect in the epidermal barrier allows breakthrough to the external and probably microbial allergens (Marsella 2006).

CAD usually occurs between $3^{\text {rd }}$ and $6^{\text {th }}$ month of age. Many studies from different periods and different geographical locations demonstrated that the following dog breeds are predisposed to CAD: West Highland White Terrier, Golden Retriever, Labrador Retriever, Bulldog (English and French), Chinese Sharr-Pei, Dalmatian and Poodle (Picco et al., 2008; Chanthick et al., 2008; Favrot et al., 2010).

Allergens that can cause CAD include house dust mites, pollen of trees, weeds and grasses, house and bed dust, fungal spores, animal and human dandruff, feathers, cigarette smoke, filling of the furniture, some bacterial allergens, insects (Chapman et al., 2007 ).

According to some authors, the primary lesion does not exist in CAD (Scott, 1981). Other authors indicated erythematous papula as a primary lesion (Chaberlain, 1974). Secondary lesions are the result of chronic pruritus and subsequent scratching, chronic inflammation of the skin and competitive secondary pyodermia and malassezia dermatitis. Partial or complete alopecia, reddish discoloration of hair because of the saliva, excoriation, papules, pustules, dry broken hair, hyper pigmentation, scaling and lichenification are noticed on the skin (Scott et al., 2001; Chanthick et al., 2008; Favrot et al., 2010).

The aim of this study was to determine the most common allergens that caused CAD in the Ambulance for skin desises of small animals of Department of equine, small animal, poultry and wild animal diseases at the Faculty of Veterinary Medicine, University of Belgrade in the period from the beginning of 2008 to the end of 2012.

\section{MATERIAL AND METHODS}

The research was conducted by using medical records of 100 dogs during a period from the beginning of 2008 to the end of 2012 in the Ambulance for 
skin diseases of small animals of Department of equine, small animal, poultry and wild animal diseases at the Faculty of Veterinary Medicine University of Belgrade. According to the documentation, all tested dogs had clinically manifest symptoms of CAD. In all animals, general clinical examination was conducted, as well as specialist dermatological examination. Determination of the presence of fleas and skin scarification has been performed.

Before testing, the hair of dogs has been cropped on the lateral part of the thorax using electric reels with insert number 40 . With a waterproof marker, spots for allergens applications, at the distance of $3 \mathrm{~cm}$ from each other, have been marked on the cropped region. The testing has been conducted on nonsedated animals placed on the table in the latero-lateral position. Intradermal testing with seasonal and non-seasonal allergens was performed by standard aqueous solutions of the allergen manufactured by the Institute of Virology, Vaccines and Sera, "Torlak". Allergens for intradermal testing are supplied in a dissolved form - glass bottles of $10 \mathrm{ml}$. The allergen solutions were stored in refrigerator $+4 \mathrm{C}^{\circ}$. In addition to performing a positive (histamine phosphate $1: 100,000 \mathrm{w} / \mathrm{v}$ ) and the negative probe ( $0.9 \%$ physiological saline solution), intradermal testing was conducted using the following 24 allergens: house dust (250 PNU / ml), Dermatophagoides sp. (250 PNU / ml), a mixture of melds (500 PNU / ml), bacterial mixture of allergen (1000 PNU / ml), mixture of feathers (500 PNU / ml), bed linen dust (1000 PNU / ml), tobacco smoke (1000 $\mathrm{PNU} / \mathrm{ml}$ ), tree pollen mixture (1000 PNU / ml), the pollen of oak - Quercus robur (1000 PNU / ml), the pollen of poplar - Populus sp. (1000 PNU / ml), the pollen of birch - Betula sp (1000 PNU / ml), pollen of hazel - Corylus sp (1000 PNU / ml), pollen of lime - Tilia sp. (1000 PNU / ml), pollen of willow - Salix sp. (1000 PNU / ml), a mixture of grass pollen (1000 PNU / ml), cock's foot pollen - Dactylis sp. (1000 PNU / ml) Timothy grass pollen - Phleum pratense $(1000 \mathrm{PNU} / \mathrm{ml})$, perennial ryegrass pollen - Lolium perene (1000 PNU / $\mathrm{ml}$ ), meadow fescue pollen - Festuca pratensis (1000 PNU / ml), a mixture of weed pollen (1000 PNU / ml), ragweed pollen - Ambrosia artemisiifolia (1000 $\mathrm{PNU} / \mathrm{ml}$ ), pollen of mugwort - Artemisia vulgaris (1000 PNU / ml), pollen of narrowleaf plantain - Plantago lanceolata (1000 PNU / ml), pollen sorrel - Rumex acetosa (1000 PNU / ml), 1:100 000, histamine phosphate, $\mathrm{w} / \mathrm{v}$ physiological saline solution $-0.9 \% \mathrm{NaCl}$. In the tests, we used 18 individual allergens and 6 mixtures of allergens, including pollen of grass, trees, weeds, feathers, melds and bacteria.

For intradermal application of allergens extracts and the positive and negative controls, $1 \mathrm{ml}$ syringes with a needle dimensions $26 \mathrm{G}(0.5 \mathrm{~mm})$ were used. On the previously marked area, $0.05 \mathrm{ml}$ of prepared allergens extracts, 
as well as positive and negative controls, was injected intradermally. Results of intradermal testing were interpreted after 15 minutes.

After this time, the reaction was measured (transparent ruler) and graduated. The reaction, which has been of the same size as the negative control has been marked as 0 , as a reaction same with the histamine +4 . Reactions marked as +2 and higher were considered positive.

\section{RESULTS}

Table 1 displays the percentage of dogs, clinically suspected for CAD, which showed positive reactions to intradermal test on individual allergens. All tested dogs were multi-sensitive to intradermal testing. In the majority of dogs, between 6 and 11 positive reactions were recorded.

Table 1: Percentage of dogs, which showed positive reaction to intradermal testing on certain allergens

\begin{tabular}{|c|c|}
\hline Allergens & $\begin{array}{l}\% \text { of dogs } \\
\text { with positive } \\
\text { reactions }\end{array}$ \\
\hline \multicolumn{2}{|l|}{ Dermatophagoides sp. ( $250 \mathrm{PNU} / \mathrm{ml})$} \\
\hline ragweed pollen - Ambrosia artemisiifolia (1000 PNU / ml) & 61 \\
\hline house dust (250 PNU / ml) & 60 \\
\hline cock's foot pollen (Dactylis sp) (1000 PNU/ml) & 59 \\
\hline mixture of weed pollen (1000 PNU/ml) & 57 \\
\hline mixture of grass pollen $(1000 \mathrm{PNU} / \mathrm{ml})$ & 56 \\
\hline pollen of willow (Salix sp) (1000 PNU/ml) & 55 \\
\hline pollen of poplar (Populus sp.) (1000 PNU/ml) & 54 \\
\hline timothy grass pollen (Phleum pratense) (1000 PNU/ml) & 47 \\
\hline perennial ryegrass pollen (Lolium perene) (1000 PNU/ml) & 45 \\
\hline tree pollen mixture $(1000 \mathrm{PNU} / \mathrm{ml})$ & 42 \\
\hline pollen of mugwort (Artemisia vulgaris) (1000 PNU/ml) & 42 \\
\hline pollen of hazel (Corylus sp.) (1000 PNU/ml) & 35 \\
\hline pollen of birch (Betula sp.) (1000 PNU/ml) & 34 \\
\hline pollen of lime (Tilia sp.) (1000 PNU/ml) & 32 \\
\hline mixture of feathers $(500 \mathrm{PNU} / \mathrm{ml})$ & 20 \\
\hline
\end{tabular}




\begin{tabular}{|l|c|}
\hline \multicolumn{1}{|c|}{ Allergens } & $\begin{array}{c}\text { \% of dogs } \\
\text { with positive } \\
\text { reactions }\end{array}$ \\
\hline bed linen dust (1000 PNU/ml) & 19 \\
\hline $\begin{array}{l}\text { pollen of narrowleaf plantain (Planta- } \\
\text { go lanceolata) (1000 PNU/ml) }\end{array}$ & 18 \\
\hline mixture of melds (500 PNU/ml) & 17 \\
\hline bacterial mixture of allergen $(1000 \mathrm{PNU} / \mathrm{ml})$ & 15 \\
\hline tobacco smoke $(1000 \mathrm{PNU} / \mathrm{ml})$ & 14 \\
\hline pollen sorrel $($ Rumex acetosa $)(1000 \mathrm{PNU} / \mathrm{ml})$ & 13 \\
\hline the pollen of oak $($ Quercus robur) $(1000 \mathrm{PNU} / \mathrm{ml})$ & 12 \\
\hline meadow fescue pollen $($ Festuca pratensis $)(1000 \mathrm{PNU} / \mathrm{ml})$ & 8 \\
\hline
\end{tabular}

\section{DISCUSSION}

In the examined dogs, the highest number of positive reactions has been registered to the following allergens: house dust mites (Dermatophagoides sp.), ragweed (A. artemisiifolia), cock's foot (Dactylis sp.), weed pollen and house dust mixture (Table 1 ).

A total of 24 allergens were used, and all dogs were multi-sensitive. In the majority of dogs, between 6 and 11 positive reactions were recorded. One dog had 23 positive reactions. Also, the results in the literature confirm that the majority of the tested dogs had been multi-sensitive (Zur et al., 2002), which indicates the complexity of the CAD pathogenesis.

According to our study, house dust mites (Dermatophagoides sp.) were the most common allergen that caused positive reaction in dogs in intradermal testing (67\%). However, literature data reported strong response in dogs (47$80 \%$ ) to that allergen at the same concentrations of $250 \mathrm{PNU} / \mathrm{ml}$ that we used (Zur et al., 2002; Tarpataki et al., 2006; Chanthick et al., 2008). House dust mites belong to the family Arachnidae and they live freely in the epidermal debris of humans, animals, yeasts, and household food remains (Spieksma, 1990). House dust is a complex allergen, which consists of house dust mites, dandruff, mold spores, insect feces, bacteria, fibrous material from plants and animals, food debris and many other substances. There are different opinions about whether house dust mite allergen should be included in the intradermal testing because of its complex structure and strong irritating effect that may lead to false-positive reactions. Based on the results of intradermal testing, positive reaction to this allergen occurs in 39.4-75.5\% of tested dogs (Willemse and Van den Brom 1983, Zur et al., 2002). In our study, reaction to house 
dust has been identified in $60 \%$ of cases, and these data are consistent with the literature reports. In our study, we used concentrations of $250 \mathrm{PNU} / \mathrm{ml}$, as recommended by other allergists (Reedy et al, 1997.; Sousa and Halliwell, 2001).

Weeds are annuals that grow wild and do not have any agricultural or decorative importance. The pollination of weeds takes place from the second half of July to November. According to data obtained by intradermal testing, weed pollen can cause a positive reaction in 2.7-45.5\% of suspected atopic individuals (Willemse and Van den Brom 1983, Zur et al., 2002; Tarpataki et al., 2006; Chanthick et al., 2008). In our survey, the weeds were identified as an important allergen in our environment (57\%), especially ragweed (61\%). This information is not surprising considering the fact that the pollen of these plants manifests strong allergenic potential (Reedy et al , 1997.). This plant is most widespread in Eastern and Central Europe, Hungary, Serbia, Croatia, Slovakia and the Czech Republic (D’Ammato et al., 1991). Also, the data from our country indicate prevalence of these plants all over Serbia, especially in Vojvodina, Mačva, Podrinje, Šumadija and in the valleys of large rivers (Janjic et al., 2007). In veterinary medicine, there are no published data on the percentage of positive reactions to this allergen (Milicic Matic et al., 2010). All American authors agree that ragweed (group of weeds) is the most important allergen in dogs and point out its strong allergenic properties (Zur et al., 2002; Tarpataki et al., 2006; Chanthick et al., 2008).

Tree pollen is one of the important allergens and, according to the literature data, $12-35 \%$ of dogs showed a positive reaction to these allergens (Willemse antigens and Van den Brom 1983, Zur et al., 2002; Tarpataki et al., 2006; Chanthick et al., 2008). According to our results, the single most important pollen allergen were willow tree (55\%) and poplar (54\%). Grass pollen is considered responsible for $10-30 \%$ of all allergies in humans. In dogs, these data are different and mostly depend of the geographical location (Willemse and Van den Brom 1983, Zur et al., 2002; Tarpataki et al., 2006; Chanthick et al., 2008). In studies conducted so far, the intradermal testing was performed using the mixture of herb extracts, as well four of single allergens extracts: cock's foot (Dactylis sp), ryegrass (Lolium perene), timothy grass (Phleum pratense) and meadow fescue (Festuca pratensis). In our study, grass pollen was present in a slightly higher percentage (56\%) as compared to the already published results.

\section{CONCLUSION}

The results of the conducted tests showed that most of the dogs with clinical signs of atopic dermatitis were multi-sensitive or demonstrated more than 
2 positive reactions to the intradermal testing. The most common allergens that cause clinical symptoms of this disease were house dust mites, following ragweed, house dust, cock's foot, weed pollen mixture, mixed grass pollen, willow and poplar.

\section{REFERENCES}

1. Chaberlain K.W.: Atopic (allergic) dermatitis. Vet Clin North Am 4, 29-39, 1974.

2. Chanthick C., Anaman S., Buathet K.: The prevalence of positive intradermal allergy tests in 114 dogs with atopic dermatitis in the Bangkok metropolis, Thailand. Veterinary Immunology and Immunopathology 126, 256-262, 2008.

3. Chapman M.D., Pomes A., Breiteneder H., Ferreira F.: Nomenclature and structural biology of allergens. J Allergy Clin Immunol 119, 414-420, 2007.

4. D’Ammato G., Spieksma F.T.M., Bonini S.: Allergenic Pollen and Pollinisis in Europe. Science Publications, Oxford, 1991.

5. Halliwell R.: Revised nomenclature for veterinary allergy. Veterinary Immunology and Immunopathology 114, 207-208, 2006.

6. Janjić V., Vrbničanin S., Stanković-Kalezić R., Radivojević L., Marisavljević D.:Poreklo i rasprostranjenost ambrozije. U: Janjić V, Vrbničanin S: Ambrozija. Herbološko društvo,Srbije Beograd, 2007, str. 17-28.

7. Milčić Matić N., Popović N., Lazarević M., Medenica Lj.: The role of Ambrosia artemisiifolia allergen in canine atopic dermatitis. Acta Veterinaria, 60, 183-196, 2010.

8. Reedy L.M., Miller W.H., Williemse T.: Allergic Skin Disease of the Dog abd Cat, 2nd Edition, WB Saunders, London, UK, 1997.

9. Scott D.W.: Observations on canine atopy. J Am Anim Hosp Assoc 17, 91$100,1981$.

10. Sousa C.A., Halliwell R.E.: The ACVD task force on canine atopic dermatitis (XI): the relationship between arthropod hypersensitivity and atopic dermatitis in the dog. Vet Immunol Immunopathol 20, 233-237, 2001.

11. Spieksma F.T.M.: Mite biology. Clinicals reviews in Allergy, 8, 31-49, 1990.

12. Tarpataki N., Papa K., Reiczgel J., Vajdovich P., Voros K.: Prevalence and features of canine atopic dermatitis in Hungary. Acta Veterinaria Hungarica 54, 353-366, 2006.

13. Willemse T., Van den Brom W.E.: Investigations of the symptomatology and the significance of immediate skin test reactivity in canine atopic dermatitis. Res Vet Sci 34, 261-265,1983. 
14. Williams H: Disease definition and measures of disease frequency. $J$ Am Acad Dermatol, 45(suppl 1), 33-6, 2001.

15. Zur G., Ihrke P.J., White S.D., Kass P.H.: Canine atopic dermatitis: a retrospective study of 266 cases examined at the University of California, Davis, 1992-1998. Vet Dermatology 13, 89-102, 2002.

16. Marsella R.: Atopic Dermatitis: A New Paradigm, Proceedings from the Hill's 2006 Symposium on Dermatology held April 2-4 in Palm Springs, CA, 2006, 7-10.

17. Picco F., Zini E., Nett C., Naegeli C., Bigler B., Rüfenacht S., Roosje P., Gutzwiller M.E., Wilhelm S., Pfister J., Meng E., Favrot C.: A prospective study on canine atopic dermatitis and food induced allergic dermatitis in Switzerland, Veterinary Dermatology 19:150-155, 2008.

18. Favrot C, Steffan J, Seewald W, Picco F.: A prospective study on the clinical features of chronic canine atopic dermatitis and its diagnosis. Vet Dermatology, 21, 1, 23-31, 2010.

19. Scott D.W., Miller W.H., Griffin C.E.: Small Animal Dermatology, 6th Edition. W.B. Saunders, Philadelphia, 2001.

Primljeno: 10.01.2014.

Odobreno: 08.07.2014. 